\title{
DENOTATIVE AND CONNOTATIVE MEANING USED IN WRITING POETRY
}

\author{
Rulik Setiani ${ }^{1}$ \\ rulik.setiani@yahoo.com
}

\section{Universitas Muhammadiyah Kotabumi}

\begin{abstract}
: the aimed of this article is to describe the use of denotative and connotative meaning in writing poetry. Writing as an activity carried out by someone in expressing thoughts, ideas, and feeling through words. There are several kinds of writing activity that someone can do; one of them is writing poetry. Poetry is one of literary works besides prose and drama, poetry consists of stanzas, lines, rhythms, and rhymes. The meaning used in poetry usually uses two meanings, there are denotative and connotative meanings, and denotative meaning is literal or actual meaning of the word itself, while denotative meaning is a meaning that has a sense and emotional feeling of the word. By using connotative or figurative language, the poetry can be seen more beautiful and contains aesthetic effect. It is also used by the poet to convey something indirectly as variations in writing poetry.
\end{abstract}

Keywords: Denotative, Connotative, Writing, Poetry

Abstrak: Tujuan dari artikel ini yaitu menjelaskan dan mendeskripsikan penggunaan makna denotasi dan konotasi dalam menulis puisi. Menulis merupakan kegiatan yang dilakukan seseorang dalam mengungkapkan pikiran, ide, ataupun perasaanya secara tertulis. Berbagai macam tulisan yang seseorang bisa lakukan, salah satunya yaitu menulis puisi, puisi ialah salah satu jenis karya sastra dimana didalamnya terdapat bait, baris, ritme, irama dan serta terkandung makna explicit atau makna denotasi dan implisit atau makna konotasi, makna denotasi yaitu makna harfiah atau makna yang sebenarnya dari suatu kata tersebut, sedangkan makna denotasi adalah makna yang memiliki nilai rasa dan emosi dari suatu kata, dengan menggunakan makna konotasi atau makna kiasan, efek estetika puisi dapat terlihat lebih indah dan jelas oleh pembaca sehingga pembaca dapat membayangkan diri pada keadaan tersebut. Disamping itu alasan lain penyair menggunakan makna kiasan atau bahasa figuratif ingin menyampaikan sesuatu secara tidak langsung sebagai variasi dalam menulis puisi.

Kata Kunci: Denotasi, Konotasi, Menulis, Puisi

\section{INTRODUCTION}

Writing activity becomes a tool to convey ideas and can make the process of thinking and creating that play a role in processing ideas (Andayani, Pratiwi, \& Priyatni in Najich and Suyitno, 2019:98). As explained Nurudin in Najich and
Suyitno (2019:98) said that by writing students can share and express ideas, thoughts and states of heart when they are sad and happy, desires and feelings.

Writing is an attempt by someone to express thoughts and ideas. Writing also aims to communicate with other people 
indirectly. In line with Tarigan in Najich and Suyitno (2019:98) who states that writing is one language skill that is not used to communicate directly and not face to face with other people. Writing skill can be applied in one of the texts, namely the poetry text. Poetry is a compacted literary work, shortened, and given a rhythm with a coherent sound and uses figurative language. According to Waluyo in Najich and Suyitno (2019:95), "poetry is a literary work that expresses the thoughts and feelings of a poet imaginatively and arranged by focusing all the power of language by physical and mental structures". In line poetry is defined as predominant experience, interpretation in rhythmic language, it also can be interpreted as a type of language that said more and more intensive than what the language said daily (Pradopo in Supriyono et al, 2018:106). In learning to write poetry, students are expected to write poetry based on the rules of writing poetry.

A good poem is a poem that can bring the readers into what is described by the poet. A poet is individual who creates poetry based on the world experience and knowledge. Based on the imaginative of the poet who was first obtained when the reader reads poetry is an experience, so more and more read as well enjoy poetry, the more experience gained and enjoyed (Tarigan in Najich and Suyitno 2019:95).
This is what distinguishes each poet has its own characteristics with other poets.

Someone who wants to write a poem is advised to use denotation and connotation because they are not separated each others; they are used in order to increase writing style. Connotation has important role in language such as in writing poetry. In line with Brinton in Hartina (2017:2) the words that have literal meanings or denotation but also evoke imaginations, feelings, attitudes, or opinions means that connotation. It can be inferred that in writing poetry, someone or poet needs using denotative and connotative meaning in their writing style.

\section{DISCUSSION}

\subsection{Writing Poetry}

Writing is a process delivery of message to the readers. It means that writing purposefully provide complete information to the readers so that they can expand knowledge and experience (Dalman in Denastiti et al, 2020:14). He also said that basically, writing has many purposes are as follows:

a) Assignment purpose: this writing is useful for the writer to his or her assignment purpose, such as papers, reports or essays.

b) Aesthetic purpose: this writing can be aimed at expressing someone's idea in aesthetic ways, like literary works for example; prose, drama, and poetry, and can be also song. 
c) Information purpose: this writing gives the information to the reader as the latest information or news, such as newspaper, magazines, and tabloids.

d) Creative purpose: it is basically pouring the ideas or thinking of someone creatively and improve and train someone's skill or hobby in certain things, such as writing song, book, novel, film script, and poetry.

e) Consumptive purpose: the writing is completed for sale and consume by the readers. Based on the previous explanation of some writing purposes, this article is focuses on writing in aesthetic and creative purposes, which is writing poetry.

Poetry is one of the literary works besides prose and drama. Sayuti in Anindita et al (2017:40) said that poetry is a form of language expression which can produces sound and rhyme in it. It expresses someone's feeling, emotional, imagination, and intellectual experience. Similarly, Yunus in Hermita (2016:19) said that poetry is one of literary works that interprets the feeling, expressing of sad and happy of the poet. In line with Waluyo in Supriyono et al (2018:105) said that poetry is a literary works that uses a condensed language, shortened, and given a unified rhythm and sound, and it uses words that contain beauty and poetic.

Gani (2014:4) said that there are three kinds of poetry based on the ways of poet expresses the content and the idea which expressed: (1) Narrative poetry is a type of poetry tells a story or experience of the poet. It also tells about something in a simple way and directly written and expressed by the poet in words, for instant romance, ballad, epic, (2) Lyric poetry is the poetry expresses lyric or poet's idea or argument, such as elegy and ode. Elegy is poetry which expresses sad feeling, besides ode is expresses admiration of something or someone, and (3) Descriptive poetry is poetry which expresses the impression of events, things that draws intention of the poet, such as satire, social criticism, and impressionistic.

According to Indriyana in Anindita and et al (2017:40) there are some syntactic elements of poetry, such as diction, imaging, concrete words, figure of speech, rhythm, and typography. The first is diction, it is form of choice and use of words, diction has important thing to raise the affectivity in writing of literary works especially poetry. The second is imaging, it is used to get the atmosphere of the poetry itself, it also used to create impression of the poet. The third is concrete words, it is the words which are used by the poet to illustrate the atmosphere or condition of the hearth with the intention of arouse the imagination of the readers in concrete words, and the readers can imagine the condition and event illustrated by the poet clearly. The fourth is figure of speech; it is 
used to create lots of meanings and rich of meanings, the words which form of figurative language can create certain effects in poetry. The fifth is rhythm, it is used as impressive strains to high turn low, short length, and loud soft utterances, and the last is typography, it is very important in writing poetry because it use to arrange the stanza, sentences, phrases, words and sounds to produce a physical form that can be able to support the content, taste, and atmosphere of the poetry.

A word in poetry has two meanings there are denotative and connotative and in writing poetry, it is important for a poet uses language style like denotation and connotation as diction of words choice, denotation and connotation are very helpful for the writer or the reader of poetry to find another interpretations and meaning out of the mind and they are easily understood of the entire meaning of the poetry which expresses by the poet (Anindita and Satoto in Zuhdah and Alfain, 2020:104). Denotation and connotation are one of semantics studies besides others. They are not separated each other and they both exist together when the poet wants to write poetry.

\subsection{Semantics}

Semantics is one of braches of linguistics; linguists want to understand how language works. Just what common knowledge do two people possess when they share a language, and it is possible for them to give and get information, to express their feeling and intentions to another. According to Kreidler. (1997:3) semantics is the systematic study of meaning, and linguistic semantics is the sturdy of how languages organize and express meanings. Moreover, Hurford et al (2007:1) said that semantics is the study of meaning in language because of this, semantics cannot be separated from word, and it is characterized as a symbolic system.

In linguistics, meaning is what the sender or source is expressed, communicated, or conveyed in their message too the receiver. In line with Richards in Agung et al. (2016:5) meaning is the key concept of communication and cognition, and there is one of the most ambiguous and controversial terms in the theory of language. According to Searly in Agung et al. (2016:5), there are some levels of meanings are as follows: the first is expression meaning (sense) is the meaning of a complex expression, the second is utterances meaning is the meaning of the expression in a given context of utterance, reference, and declarative sentence, and the last is communicative meaning is the meaning of an utterance as a communicative act in a given social setting. According to Leech in Umagandhi and 
Vinothini (2017:1) semantics can break down "meaning" the meaning can be classified into seven types, there are denotative or conceptual meaning (meaning by dictionary), connotative meaning (meaning by suggest of mind), social meaning (social context), reflected meaning, affective or emotive meaning (personal feeling), collocative meaning (association of words), and thematic meaning (message of meaning). Based on the types of the meaning above, the writer focuses to discuss two of them, denotative and connotative meaning.

\subsection{Denotative}

A denotation is identified as the central aspect of word meaning, means that it is called as literal meaning, the meaning as same as dictionary meanings which is everybody generally, agrees about. According to Isfandiyary in Zuhdah and Alfain (2020:105) denotation is commonly defined as literal meaning or a word which has only one specific meaning. In other words, it is the basic meaning of visual signs. For example, the word "home" in denotative, there is no other meaning except a place where person lives in. The other example is "rose" the denotative meaning is plant in flower categories that has thorns in stems and petals and usually red, white, and pink colors, and so on.
Moreover; Arifin and Tasai in Tudjuka (2018:4), denotative meaning has explicitly meaning and according to what it is. It is commonly given an explanation as a meaning based on the result of sight, smell, hearing, feeling, or other experience. So, denotative meaning concerns objective factual information. It can be inferred that denotative meaning is also known as conceptual meaning deals with the core meaning of expression or literal meaning.

\subsection{Connotative}

Connotation can be defined to the wide collection of positive and negative associations that most words carry with them, it is also as a word means something else, the additional meaning or sense value contained in a word (Elnaili in Zuhdah and Alfain (2020:105). For example, the word "home" in connotative, the meaning can be love, comfort, and family.

Connotation refers to the personal aspect of meaning, the emotional associations that the word arouses. Connotations vary according to the experience of individuals because people do have common experiences; some words have shared connotations, it is called has a connotative meaning when the word has a taste value both positive and negative, if it has no taste value then said not to have connotation (Kreidler, 1997:45). It can be 
concluded that connotation is an idea that can be associated a word, a word can be suggested to one or more meanings, and it can be also called as figurative language or figure of speech.

Wardoyo (2013:25-29) said that figurative language or figure of speech which is often used in writing poetry consists of four types, namely:

\section{a) Personification}

Personification is one of figurative languages which consider inanimate objects to have human-like characteristics; it is also equating objects with human behavior. In other words those inanimate objects can think and do anything as human-like. As for example of personification; "two sunflowers move into the yellow room by Nancy Willard" it is known that sunflowers cannot be tired or talk, so Willard uses personification to give them this attributes. The other example is "the stars danced playfully in the moonlit sky" the second example also signify personification of the word "danced" that truly stars cannot dance as human can.

b) Metaphor

A metaphor is a figurative language used to describe something as if was something else, it makes a comparison directly relating one thing to another unrelated things that are not actually the same, and the audience understands that it is a comparison, not a literal equation. A poet uses metaphor to add color and emphasis to what he or she is trying to express. For instant, a sea of knowledge" it means to express how smart or educated they are. Knowledge and sea are not literally related, but they are figuratively related because they are both immense things that are difficult to measure. By putting them together, it can accentuate how vast a person's knowledge is.

c) Simile

a simile is a literary term to compare two different things and show a common quality between them, it usually uses the word "like" and "as" two compare two things, for example; "she smiles like the sun" it compares a woman with something of a different kind-the sun.

d) Hyperbole

Hyperbole is figurative language used by the poet to show and express an event or something excessively. For example; "as I walked out one evening" this poem of W.H. Auden was an English-American poet who often used hyperbole, he expressed his everlasting love. 


\section{CONCLUSION}

Based on the previous explanation, the writer concludes that in writing poetry, the poet can use two meanings of language beside other meanings, as diction or style to write the poetry, they are denotative meaning where the poet uses it to convey the literal meaning or real words as the meaning in dictionary, not only that he or she also can use connotative meaning or associative meaning means that when a word suggests a set of associations, the readers can associate by an imagination, emotional, and felling. They (denotative and connotative) are used to enable the poet to explore a sense of the meaning of the poetry that he/she writes.

\section{REFERENCES}

Agung, N. Satriyono et al. 2016. A Sematic Analysisi of Denotative Meaning in Kidung Doa Song by Sunan Kalijaga. Jurnal Ilmiah Bahasa dan Sastra, 1 Juni 2016, Volume 3, No.1.

Anindita, Andyan, Kun \& Sumarlan, Satoto Soediro. 2017. Diction in Poetry Anthology Surat Kopi by Joko Pinurbo as a Poetry Writing Teaching Material. [Online]. International Journal of Active Learning. Volume 2, No. 1, Available: http://journal.unnes.ac.id/nju/index.php/ijal [1st of April 2017]

Denastiti et al. 2020. Menulis Puisi Berbasis Musik Pop. Jurnal Didactique Bahasa Indonesia, January 2020, Vol. 1 No.1.

Gani, Erizal. 2014. Kiat Pembacaan Puisi, Teori dan Terapan. Bandung: Pustaka Reka Cipta.

Hermitha, Maudy. 2016. Penguasaan Diksi Terhadap Keterampilan Menulis Puisi Baru. Semarang: UNNES Press.

Hurford et al. 2007. SEMANTICS: A coursebook (Second Edition). London. Cambridge University Press.

Kreidler.W.Charles. 1997. Introducing English Semantics. London and New York: Routledge.

Najich, Rifqy, Muhammad \& Suyitno, Imam. 2019. Diksi dalam Puisi Kelas VIII SMP Negeri 3 Singosari. [Online]. Journal Kajian Bakasa, Sastra Indonesia, dan Pembelajaranya, Volume 3, No.1, Available: http://journal2.um.ac.id/index.php/basindo [31 ${ }^{\text {st }}$ of May 2019]

Supriyono, Sugeng et al. 2018. Diksi Konotatif Puisi-Puisi Subagio Sastrowardoyo dan Implementasinya dalam Pembelajaran Apesiasi Sastra di SMA. [Online] Jurnal Penelitian Pendidikan Bahasa dan Sastra Indonesia. Volume 4, No. 1, Available: https://doi.org/10.2220/JG.2018.V4i1.2460. 
Tudjuka, S. Nina. 2018. Makna Denotasi dan Konotasi pada Ungkapan Tradisional dalam Konteks Pernikahan Adat Suku Pamona. [Online] Jurnal Bahasa dan Sastra. Volume 3, No. 2.

Umagandhi, R. \& Vinothini, M. 2017. Leech's seven types of Meaning in Semantics. [Online] International Journal of Multidisciplinary Research and Development. Volume 4, No.3, Available: www.allsubjectjournal.com.

Wardoyo, S. Mangun. 2013. Teknik Menulis Puisi. Yogyakarta: Graha Ilmu.

Zuhdah, Rahmatika, Daumi \& Alfain, I.N. Shinta. 2020. An Analysis of Denotation and Connotation in Chairil Anwar's Poem. [Online] e-Journal of Linguistics. Volume 14, No. 1, Avilable: http://doi.org/10.24843/e-j1.2020.v14.i01.p011 